\title{
Investigation of Inlet Gas Streams Effect on the Modified Claus Reaction Furnace
}

\author{
Reza Rezazadeh ${ }^{1}$, Sima Rezvantalab ${ }^{2 *}$ \\ ${ }^{1}$ Shahid Hasheminejad Gas Processing Company (S.G.P.C), Khangiran, Iran \\ ${ }^{2}$ Department of Chemical Engineering, Urmia University of Technology, Urmia, Iran \\ Email:"sima_rezvan@yahoo.com
}

Received May 30, 2013; revised June 30, 2013; accepted July 30, 2013

Copyright (C) 2013 Reza Rezazadeh, Sima Rezvantalab. This is an open access article distributed under the Creative Commons Attribution License, which permits unrestricted use, distribution, and reproduction in any medium, provided the original work is properly cited.

\begin{abstract}
The objective of this paper is to model the main reactions that take place in the Claus reactor furnace and compare it with actual data and simulated process. Since the most important point is the selection of suitable reaction conditions to increase the reactor performance, the model is formulated to predict the performance of the Claus plant. To substantiate the theoretical model, we used actual process condition and feed composition in Shahid Hasheminejad Gas Refinery. Model equations have been solved by using MATLAB program. Results from MATLAB are compared with those from SULSIM $^{\mathbb{R}}$ simulator and with actual plant data. The AAD (Average Absolute Deviation) of modeling results with actual data is $2.07 \%$ and AAD of simulation results with real data is $4.77 \%$. Error values are very little and show accuracy and precision of modeling and simulation. The predicting curve for different parameters of the reactor furnace according to variable conditions and specifications are given.
\end{abstract}

Keywords: Claus Process; Hydrogen Sulfide; Modeling; Reactor Furnace

\section{Introduction}

Hydrogen sulfide $\left(\mathrm{H}_{2} \mathrm{~S}\right)$ is produced from sulfur compounds in fossil fuels such as natural gas or oil. Sour gases $\left(\mathrm{H}_{2} \mathrm{~S}\right.$ and $\left.\mathrm{CO}_{2}\right)$, are removed from the natural gas or refinery gas by means of one of the gas treating processes. Due to global environmental rules, refineries have to recover sulfur from nature. $\mathrm{H}_{2} \mathrm{~S}$ containing acid gas stream is flared, incinerated, or fed to a sulfur recovery unit. The Claus process is commonly used to reduce the emission of sulfur compounds into the atmosphere. Recently recovery of sulfur is done by means of the modified Claus tail gas clean-up processes. In these processes, $\mathrm{H}_{2} \mathrm{~S}$ over a catalyst converts to elemental sulfur where the reaction takes place in a high temperature furnace. The recovery process is the reaction between $\mathrm{H}_{2} \mathrm{~S}$ and air to form sufur and water. Following reaction is the main reaction in the recovery process:

$$
\mathrm{H}_{2} \mathrm{~S}+\frac{1}{2} \mathrm{O}_{2} \rightarrow \frac{1}{x} \mathrm{~S}_{x}+\mathrm{H}_{2} \mathrm{O}+\text { heat }\left(\cong 626000 \frac{\mathrm{KJ}}{\text { Kgmole }}\right)
$$

In the original Claus process, control of this reaction was difficult and sulfur recovery efficiencies were low.

\footnotetext{
${ }^{*}$ Corresponding author.
}

In order to overcome these difficulties and also increase the efficiency of the process, several modifications of the Claus process have been developed. In modified process, free flame total oxidation of $1 / 3$ of the $\mathrm{H}_{2} \mathrm{~S}$ to $\mathrm{SO}_{2}$ followed by a reaction over the catalyst of $\mathrm{SO}_{2}$ with the remaining 2/3 $\mathrm{H}_{2} \mathrm{~S}$. According to Mohamed Sassi and Ashwani K. Gupta modified Claus process for a Sulfur Recovery Plant consists of several stages [1]:

1) Combustion (In the Reactor Furnace)

$$
\begin{aligned}
& \mathrm{H}_{2} \mathrm{~S}+3 / 2 \mathrm{O}_{2} \stackrel{\text { High T }}{\longrightarrow} \mathrm{SO}_{2}+\mathrm{H}_{2} \mathrm{O} \\
&+ \text { heat }(\cong 518000 \mathrm{KJ} / \text { Kgmole }) \\
& 2 \mathrm{H}_{2} \mathrm{~S}+\mathrm{SO}_{2} \stackrel{\text { High T }}{\longleftrightarrow} 3 / 2 \mathrm{~S}_{2}+2 \mathrm{H}_{2} \mathrm{O} \\
& \Delta \mathrm{H}_{\mathrm{R}} \cong+47000 \mathrm{KJ} / \text { Kgmole }
\end{aligned}
$$

2) Redox (Catalytic Converter)

These are simplified reactions which actually take place in a Claus unit. There are various species of gaseous sulfur $\mathrm{S}_{2}, \mathrm{~S}_{3}, \mathrm{~S}_{4}, \mathrm{~S}_{5}, \mathrm{~S}_{6}, \mathrm{~S}_{7}$, and $\mathrm{S}_{8}$. Equilibrium concentrations of these sulfur compounds are not known in the

$$
\begin{aligned}
2 \mathrm{H}_{2} \mathrm{~S}+\mathrm{SO}_{2} \stackrel{\text { Catalytic, Low } \mathrm{T}}{\longrightarrow} & \frac{3}{X} \mathrm{~S}_{x}+2 \mathrm{H}_{2} \mathrm{O}+\text { heat } \\
& (\cong 108 \mathrm{KJ} / \text { Kgmole })
\end{aligned}
$$




$$
\begin{aligned}
& 3 \mathrm{H}_{2} \mathrm{~S}+3 / 2 \mathrm{O}_{2} \stackrel{\text { Overall }}{\longrightarrow} \frac{3}{X} \mathrm{~S}_{X}+3 \mathrm{H}_{2} \mathrm{O}+\text { heat } \\
&(\cong 626000 \mathrm{KJ} / \text { Kgmole })
\end{aligned}
$$

entire of process. Additionally, gas stream contains water saturated with 15 - $80 \mathrm{~mol}^{\circ} \mathrm{H}_{2} \mathrm{~S}, 0.5$ - $1.5 \mathrm{~mol} \%$ hydrocarbons, and $\mathrm{CO}_{2}$ which can result in carbonyl sulfide (COS) carbon disulfide $\left(\mathrm{CS}_{2}\right)$, carbon monoxide $(\mathrm{CO})$, and hydrogen [2].

Most Claus plants operate in the multistep process "straight-through" mode as shown in Figure 1. The combustion is carried out in a reducing atmosphere with only enough air 1) to oxidize one-third of the $\mathrm{H}_{2} \mathrm{~S}$ to $\mathrm{SO}_{2}$, 2) to burn hydrocarbons and mercaptans, and 3) for many refinery Claus units, to oxidize ammonia and cyanides. The process includes the following operations:

- Combustion: burn hydrocarbons and other combustibles and oxidize one-third of the $\mathrm{H}_{2} \mathrm{~S}$ to provide necessary $\mathrm{SO}_{2}$ to react with remainder $\mathrm{H}_{2} \mathrm{~S}$ for producing $\mathrm{S}_{2}$ in the furnace.

- Waste Heat Recovery: Cool combustion products.

- Sulfur Condensing: Cool outlet streams from waste heat recovery unit and from catalytic converters.

- Reheating: Reheat process stream, after sulfur condensation and separation, to a temperature high enough to remain sufficiently above the sulfur dew point.

In order to investigate different aspects of the modified Claus process, a number of studies have been performed on main burner and sulfur recovery in this process. Monnery et al. modeled the modified Claus process [3]. Kelly Anne Hawboldt has studied mathematical modeling of reactions in the process [4]. Recently, S. Asadi et al. used TSWEET simulator to optimize the recovery of sulfur [5].

At first approach, we have used a mathematical model for the key reactions that take place in the reactor furnace. In the second approach, we have simulated the process with a commercial simulator. Finally using the model and simulation, we have compared obtained results and proposed some improvements on the base case.

\section{Kinetic Studies}

Claus process has been investigated via different aspects, experimental and theoretical perspectives. Paskal et al. gives a summary of the main reactions thought to occur within the Claus furnace [6,7]. Clark et al. discussed the mechanisms behind the formation of key sulfur containing species found within the furnace, and in a subsequent study outline primary reaction pathways for the principal components in the furnace $[8,9]$. While there have been numerous attempts to model the Claus process based on simplified kinetic expressions, the complexity of the chemistry and the number of involved reactions has precluded the accurate prediction of outlet compositions. As it mentioned before, gas stream contains different compounds such as $\mathrm{H}_{2} \mathrm{~S}, \mathrm{CO}_{2}$ and hydrocarbons. Most important compound is $\mathrm{H}_{2} \mathrm{~S}$ and several groups have studied it's decomposition under different condition. As result, it suggested that there are numerous reactions on the catalytic decomposition of $\mathrm{H}_{2} \mathrm{~S}$ in the clause process. According to the studies, gaseous $\mathrm{H}_{2} \mathrm{~S}$ exists in chemical equilibrium with elemental hydrogen and sulfur by the following equation:

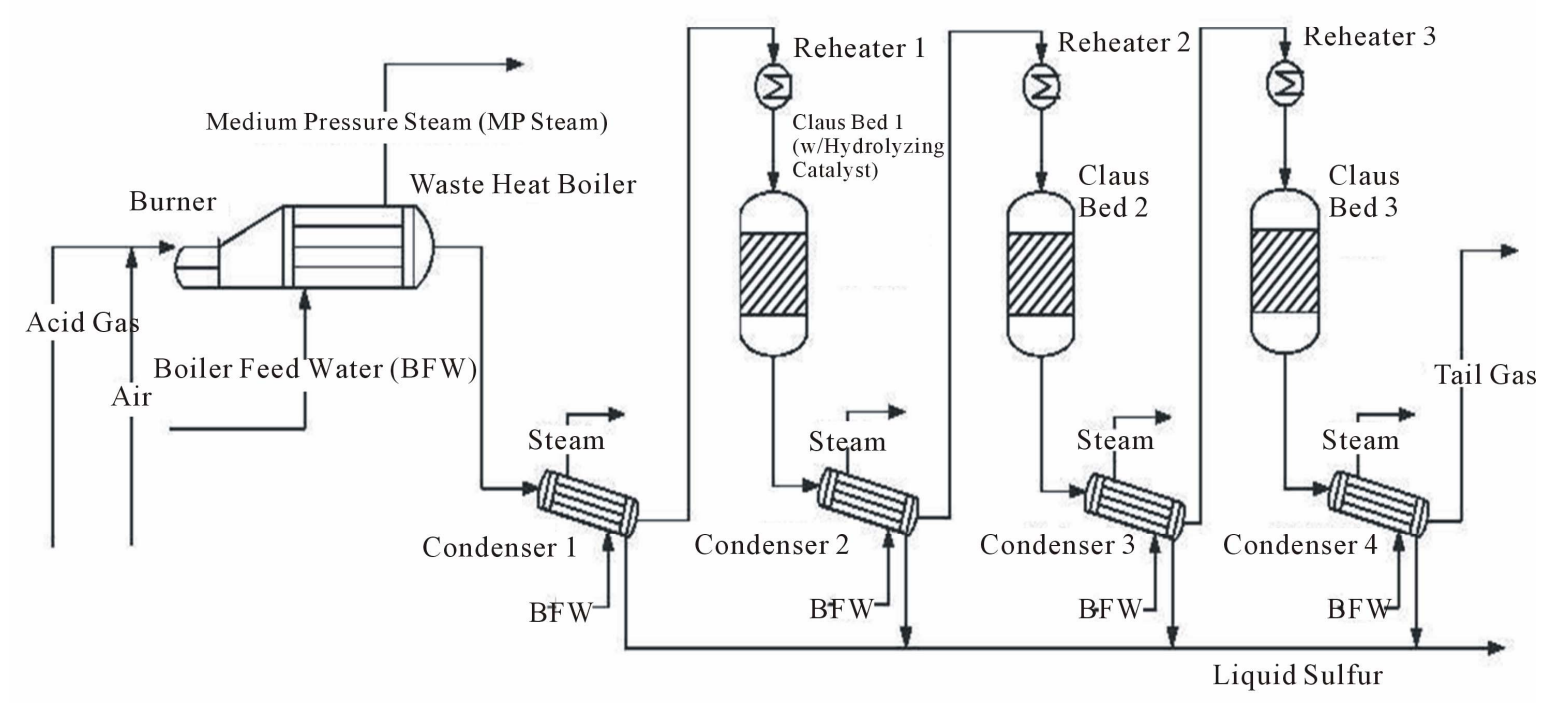

Figure1. Three-stage straight-through sulfur plant. 


$$
\mathrm{H}_{2} \mathrm{~S} \leftrightarrow \mathrm{H}_{2}+\frac{1}{x} \mathrm{~S}_{x}
$$

Oxidation includes two staged reaction, first oxidation of $\mathrm{H}_{2} \mathrm{~S}$ and followed by reaction between $\mathrm{H}_{2} \mathrm{~S}$ and $\mathrm{SO}_{2}$ that limiting stage of the Claus reaction is the second part [10].

$$
\begin{aligned}
& \mathrm{H}_{2} \mathrm{~S}+\frac{3}{2} \mathrm{O}_{2} \leftrightarrow \mathrm{H}_{2} \mathrm{O}+\mathrm{SO}_{2} \\
& 2 \mathrm{H}_{2} \mathrm{~S}+\mathrm{SO}_{2} \leftrightarrow 2 \mathrm{H}_{2} \mathrm{O}+\mathrm{S}_{2}
\end{aligned}
$$

During the reaction in the furnace and according to the existence of ammonia in the gas stream, oxidation of $\mathrm{NH}_{3}$ will take place. Recently, Clark has mentioned that under $1100^{\circ} \mathrm{C}$ ammonia oxidation is negligible. Additionally, he noted in competitive oxidation, first of all $\mathrm{H}_{2} \mathrm{~S}$, and then methane, finally $\mathrm{NH}_{3}$ react. On the other hand, Goar et al. found rate of hydrocarbon combustion is more than ammonia and $\mathrm{NH}_{3}$ is more than $\mathrm{H}_{2} \mathrm{~S}$ [11]. Formation of COS and $\mathrm{CS}_{2}$ in the Claus reaction furnace are also very important in the modeling. Field studies have revealed that concentrations of $\mathrm{COS}$ and $\mathrm{CS}_{2}$ at the exit of the reaction furnace/ waste heat boiler typically lie between $100 \mathrm{ppm}$ and $2 \mathrm{~mol} \%$ [12]. However, these seemingly small concentrations in the furnace product stream can represent nearly half the sulfur emissions from a tail gas clean-up unit [13]. It is possible to hydrolyze $\mathrm{COS}$ and $\mathrm{CS}_{2}$ back into $\mathrm{H}_{2} \mathrm{~S}$ in the Claus catalytic converters according to the following stoichiometry:

$$
\begin{aligned}
& \mathrm{COS}+\mathrm{H}_{2} \mathrm{O} \leftrightarrow \mathrm{CO}_{2}+\mathrm{H}_{2} \mathrm{~S} \\
& \mathrm{CS}_{2}+2 \mathrm{H}_{2} \mathrm{O} \leftrightarrow \mathrm{CO}_{2}+2 \mathrm{H}_{2} \mathrm{~S}
\end{aligned}
$$

As it mentioned, there many reactions which may take place in the furnace according to the conditions such as temperature and pressure. Full list of reactions that occur in the furnace is not obvious and for the known reactions, reaction rate expressions are not available. In current work we assumed that gas stream consists of $\mathrm{CH}_{4}, \mathrm{CO}_{2}, \mathrm{H}_{2} \mathrm{~S}$, $\mathrm{H}_{2} \mathrm{O}, \mathrm{O}_{2}, \mathrm{~N}_{2}, \mathrm{CO}, \mathrm{CS}_{2}, \mathrm{COS}, \mathrm{S}_{2}, \mathrm{SO}_{2}, \mathrm{H}_{2}$. Regarding gas stream composition, important reactions which take place in furnace and we use in the modeling are listed below.

$$
\begin{gathered}
\mathrm{H}_{2} \mathrm{~S}+3 / 2 \mathrm{O}_{2} \rightarrow \mathrm{SO}_{2}+\mathrm{H}_{2} \mathrm{O} \\
2 \mathrm{H}_{2} \mathrm{~S}+\mathrm{SO}_{2} \leftrightarrow 3 / 2 \mathrm{~S}_{2}+2 \mathrm{H}_{2} \mathrm{O} \\
\mathrm{CH}_{4}+2 \mathrm{O}_{2} \rightarrow \mathrm{CO}_{2}+2 \mathrm{H}_{2} \mathrm{O} \\
\mathrm{CO}_{2} \rightarrow \mathrm{CO}+1 / 2 \mathrm{O}_{2} \\
\mathrm{H}_{2} \mathrm{~S} \rightarrow 1 / 2 \mathrm{~S}_{2}+\mathrm{H}_{2} \\
\mathrm{CH}_{4}+2 \mathrm{~S}_{2} \rightarrow \mathrm{CS}_{2}+2 \mathrm{H}_{2} \mathrm{~S} \\
\mathrm{CO}+1 / 2 \mathrm{~S}_{2} \rightarrow \mathrm{COS}
\end{gathered}
$$

\section{Mathematical Model}

The basic structure of the model consist of the equations of mole and energy conservative rule the furnace, which are related to each other and are function of molar conversion of $\mathrm{H}_{2} \mathrm{~S}$ in equilibrium reaction and temperature. In order to model the reactor, a steady-state simulation has been used for mole and energy balance.

Sames and Paskal presented empirical correlations to predict the fraction of $\mathrm{CO}, \mathrm{H}_{2}, \mathrm{COS}, \mathrm{CS}_{2}$ and sulfur (as $\mathrm{S}$ ) in the effluent of the Claus furnace. The correlations are obtained from more than 300 tests on 100 different sulfur trains; with different flow configurations processing acid gas feed streams [12]. These empirical correlations are presented in Appendix. We use these equations to model the furnace and mole balance. In this work, furnace pressure is $130 \mathrm{kPa}$ (absolute) and pressure drop $(\Delta \mathrm{P})$ is $10 \mathrm{kPa}$. Using empirical equations and applying in the mole balance for the compounds, we get the mole balance equations, for each compound.

For gas components in the outlet gas stream: $\mathrm{H}_{2} \mathrm{~S}$ :

$$
\begin{aligned}
& f_{i\left(\mathrm{H}_{2} \mathrm{~S}\right)}+2 R\left(\mathrm{CS}_{2}\right) \times\left(f_{i\left(\mathrm{CH}_{4}\right)}\right)-f_{i\left(\mathrm{H}_{2} \mathrm{~S}\right)}-\frac{1}{3} f_{i\left(\mathrm{H}_{2} \mathrm{~S}\right)} \\
& -R\left(\mathrm{H}_{2}\right) \times f_{i\left(\mathrm{H}_{2} \mathrm{~S}\right)}-X
\end{aligned}
$$

$\mathrm{H}_{2} \mathrm{O}: f_{i\left(\mathrm{H}_{2} \mathrm{O}\right)}+2\left(1-R\left(\mathrm{CS}_{2}\right)\right) \times f_{i\left(\mathrm{CH}_{4}\right)}+\frac{1}{3} f_{i\left(\mathrm{H}_{2} \mathrm{~S}\right)}+X$

$$
\mathrm{CO}_{2} \text { : }
$$$$
f_{i\left(\mathrm{CO}_{2}\right)}+f_{i\left(\mathrm{CH}_{4}\right)} \times\left(1-R\left(\mathrm{CS}_{2}\right)\right)
$$$$
-(R(\mathrm{COS})+R(\mathrm{CO})) \times f_{i\left(\mathrm{CH}_{4}\right)}+f_{i\left(\mathrm{CO}_{2}\right)}
$$

CO:

$$
R(\mathrm{CO}) \times\left(f_{i\left(\mathrm{CH}_{4}\right)}+f_{i\left(\mathrm{CO}_{2}\right)}\right)
$$

$\mathrm{SO}_{2}$ :

$$
\frac{1}{3} f_{\mathrm{i}\left(\mathrm{H}_{2} \mathrm{~S}\right)}-\frac{1}{2} X
$$

$\mathrm{CH}_{4}$ :

$$
0
$$

$\mathrm{O}_{2}: \quad \frac{1}{2}(R(\mathrm{COS}))+R(\mathrm{CO}) \times\left(f_{i\left(\mathrm{CH}_{4}\right)}+f_{i\left(\mathrm{CO}_{2}\right)}\right)$

$\mathrm{N}_{2}: \quad \frac{79}{21} f_{i\left(\mathrm{H}_{2} \mathrm{~S}\right)}+2 f_{i\left(\mathrm{CH}_{4}\right)}\left(1-R\left(\mathrm{CS}_{2}\right)\right) \times \frac{1}{2}$

$\mathrm{S}_{2}: \quad \frac{3}{4} X R(\mathrm{COS}) \times\left(f_{i\left(\mathrm{CH}_{4}\right)}+f_{i\left(\mathrm{CO}_{2}\right)}\right)+\frac{1}{2} f_{i\left(\mathrm{H}_{2} \mathrm{~S}\right)}$

$$
-2 R\left(\mathrm{CS}_{2}\right) \times f_{i\left(\mathrm{CH}_{4}\right)}-\frac{1}{2} R\left(\mathrm{H}_{2}\right)
$$

$\mathrm{H}_{2}$ :

$$
R\left(\mathrm{H}_{2}\right) \times f_{i\left(\mathrm{H}_{2} \mathrm{~S}\right)}
$$

$\mathrm{CS}_{2}$ :

$$
R\left(\mathrm{CS}_{2}\right) \times f_{i\left(\mathrm{CH}_{4}\right)}
$$

COS: $\quad \mathrm{R}(\mathrm{COS}) \times\left(f_{i\left(\mathrm{CH}_{4}\right)}+f_{i\left(\mathrm{CO}_{2}\right)}\right)$ 
Total moles:

$$
\begin{aligned}
& f_{i\left(\mathrm{CH}_{4}\right)}\left(3-2 R\left(\mathrm{CS}_{2}\right)+\frac{1}{2} R(\mathrm{CO})\right) \\
& +f_{i\left(\mathrm{CO}_{2}\right)}\left(1-R\left(\mathrm{CS}_{2}\right)+\frac{1}{2} R(\mathrm{CO})\right) \\
& +f_{i\left(\mathrm{H}_{2} \mathrm{~S}\right)}\left(\frac{4}{3}+\frac{1}{2} R\left(\mathrm{H}_{2}\right)\right)+f_{i\left(\mathrm{~N}_{2}\right)}+f_{i\left(\mathrm{H}_{2} \mathrm{O}\right)}+\frac{1}{4} X
\end{aligned}
$$

$\mathrm{X}$ : Flow rate of $\mathrm{H}_{2} \mathrm{~S}$ conversion at the equilibrium Claus reaction

At equilibrium:

$$
K_{p}=\frac{\left[\mathrm{H}_{2} \mathrm{O}\right]^{2}\left[\mathrm{~S}_{2}\right]^{3 / 2}}{\left[\mathrm{H}_{2} \mathrm{~S}\right]^{2}\left[\mathrm{SO}_{2}\right]}\left[\frac{\pi}{\text { total mols }}\right]^{3 / 2-1}
$$

By interpolation in the $K_{p}$ curve vs. furnace temperature (GPSA), we calculate:

$$
K_{p}=0.6021 T-420.49 T\left({ }^{\circ} \mathrm{C}\right), K_{p}\left(\mathrm{Kpa}^{0.5}\right)
$$

Replacing molar flows in Equation (18) through 30 in Equation (31) resulted into a new equation, function of temperature, in the following form (see below):

where the A, B, C, D are function of feed composition and would be calculated numerically.

In order to calculate the reactions enthalpy, we used equation 34 and data provided in Table 1. Table 1 represents standard enthalpy of formation and heat capacity parameters for each component.

$$
\operatorname{SUM}\left(\Delta H_{r x n}\right)=\sum_{1}^{7} \Delta H_{r x n} \times f_{r x n(i)} \times \text { Conversion }_{i}
$$

$\Delta H_{r x n}$ is standard enthalpy of reactions in $25^{\circ} \mathrm{C}, f_{r x n(i)}$ is molar flow rate of limiting compound in each reaction, Conversion $_{i}$ is conversion value of limiting compound in each reaction.

Replacing all mentioned equations resulted into a new Equation (35) in which conversion of $\mathrm{H}_{2} \mathrm{~S}$ is function of temperature of reaction furnace (Table 2).

$$
X=\frac{A_{0}+A_{4} T+B_{4} T^{2}+C_{4} T^{3}+D_{4} T^{4}}{B_{0}+A_{5} T+B_{5} T^{2}+C_{5} T^{3}+D_{5} T^{4}}
$$

$A_{0}, A_{4}, A_{5}, B_{0}, B_{4}, B_{5}, C_{4}, C_{5}, D_{4}, D_{5}$ are constant parameters that would calculated numerically according to the inlet gas stream condition.

In order to establish a reference point, calculations are carried out for a "base case" and the operating conditions used are given in Table 3. Our base case is Shahid Hasheminejad Gas Refinery. Shahid Hasheminejad (Khangiran) gas refinery is in Sarakhs, Khorasan province.
Operating conditions is composition of inlet gas stream to the Claus process in the refinery. Next step, application of the feed gas condition in the equations resulted into the parameters of mole and energy balance equations. Calculated parameters are presented in Table 4.

\section{Process Simulation}

In order to compare the implications of the reaction fur-

Table1. Compound heat capacity parameters and $\mathrm{H}_{298}{ }^{0}$ $\mathrm{kJ} / \mathrm{kg}$ mole.

\begin{tabular}{cccccc}
\hline & $\mathrm{a}_{\mathrm{i}}$ & $\mathrm{b}_{\mathrm{i}}$ & $\mathrm{c}_{\mathrm{i}}$ & $\mathrm{d}_{\mathrm{i}}$ & $\begin{array}{c}H_{(i, 298)}^{0} \text { at } 25^{\circ} \mathrm{C} \\
\mathrm{kJ} / \mathrm{kgmole}\end{array}$ \\
\hline $\mathbf{C H}_{4}$ & 34.31 & 0.05469 & $3.66 \times 10^{-6}$ & $-11 \times 10^{-9}$ & 881 \\
$\mathbf{C O}_{2}$ & 19.8 & 0.0734 & $-5.6 \times 10^{-5}$ & $1.72 \times 10^{-8}$ & 912 \\
$\mathbf{H}_{2} \mathbf{S}$ & 31.94 & $1.44 \times 10^{-3}$ & $2.43 \times 10^{-5}$ & $-1.18 \times 10^{-8}$ & 846 \\
$\mathbf{H}_{2} \mathbf{O}$ & 32.2 & $1.92 \times 10^{-3}$ & $1.06 \times 10^{-5}$ & $3.6 \times 10^{-9}$ & 839 \\
$\mathbf{O}_{2}$ & 29.1 & $11.58 \times 10^{-3}$ & $-6.0759 \times 10^{-6}$ & $13.11 \times 10^{-10}$ & 733 \\
$\mathbf{N}_{2}$ & 21.15 & $13.6 \times 10^{-4}$ & $2.6 \times 10^{-5}$ & $-1.17 \times 10^{-8}$ & 726 \\
$\mathbf{S O}_{2}$ & 23.85 & $67 \times 10^{-3}$ & $-4.9 \times 10^{-5}$ & $1.33 \times 10^{-8}$ & 986 \\
$\mathbf{S}_{2}$ & 32.47 & 0.0067 & 0 & 0 & 805 \\
$\mathbf{C O}$ & 30.87 & $-12.9 \times 10^{-3}$ & $2.79 \times 10^{-5}$ & $-1.27 \times 10^{-8}$ & 729 \\
$\mathbf{C S}_{2}$ & 27.44 & $81.3 \times 10^{-3}$ & $-7.67 \times 10^{-5}$ & $2.87 \times 10^{-8}$ & 1127 \\
$\mathbf{C O S}_{\mathbf{O}}$ & 23.57 & $79.8 \times 10^{-3}$ & $-7.02 \times 10^{-5}$ & $2.45 \times 10^{-8}$ & 1025 \\
$\mathbf{H}_{2}$ & 27.14 & $9.27 \times 10^{-3}$ & $-1.38 \times 10^{-5}$ & $7.65 \times 10^{-9}$ & 719 \\
\hline
\end{tabular}

Table 2. limiting specie and calculated $\Delta H_{\mathrm{rxn}}$ [4].

\begin{tabular}{ccc}
\hline Limiting specie & Reactions & $\Delta \mathrm{H}_{\mathrm{rxn}}(\mathrm{Kj} / \mathrm{kgmole})$ \\
\hline $\mathrm{CO}_{2}$ & $\mathrm{CO}_{2} \rightarrow \mathrm{CO}+1 / 2 \mathrm{O}_{2}$ & 280000 \\
$\mathrm{H}_{2} \mathrm{~S}$ & $\mathrm{H}_{2} \mathrm{~S}+3 / 2 \mathrm{O}_{2} \rightarrow \mathrm{SO}_{2}+\mathrm{H}_{2} \mathrm{O}$ & -520000 \\
$\mathrm{CH}_{4}$ & $\mathrm{CH}_{4}+2 \mathrm{O}_{2} \rightarrow \mathrm{CO}_{2}+2 \mathrm{H}_{2} \mathrm{O}$ & -803000 \\
$\mathrm{H}_{2} \mathrm{~S}$ & $2 \mathrm{H}_{2} \mathrm{~S}+\mathrm{SO}_{2} \leftrightarrow 3 / 2 \mathrm{~S}_{2}+2 \mathrm{H}_{2} \mathrm{O}$ & 46500 \\
$\mathrm{H}_{2} \mathrm{~S}$ & $\mathrm{H}_{2} \mathrm{~S} \rightarrow 1 / 2 \mathrm{~S}_{2}+\mathrm{H}_{2}$ & 81000 \\
$\mathrm{CH}_{4}$ & $\mathrm{CH}_{4}+2 \mathrm{~S}_{2} \rightarrow \mathrm{CS}_{2}+2 \mathrm{H}_{2} \mathrm{~S}$ & -296000 \\
$\mathrm{CO}$ & $\mathrm{CO}+1 / 2 \mathrm{~S}_{2} \rightarrow \mathrm{COS}$ & -142000 \\
\hline
\end{tabular}

Table 3. Refinery claus process inlet gas condition.

\begin{tabular}{cc}
\hline Feed Temperature & $325 \mathrm{~K}\left(52^{\circ} \mathrm{C}\right)$ \\
Inlet air temperature & $350 \mathrm{~K}\left(77^{\circ} \mathrm{C}\right)$ \\
(average in summer and winter) & $130 \mathrm{kPa} \mathrm{A}$ \\
Furnace pressure & $2682.9 \mathrm{Kgmole} / \mathrm{h}$ \\
Feed molar rate & 0.0105 \\
$\mathrm{CH}_{4}$ mole fraction & 0.563 \\
$\mathrm{CO}_{2}$ mole fraction & 0.336 \\
$\mathrm{H}_{2} \mathrm{~S}$ mole fraction & 0.0905 \\
$\mathrm{H}_{2} \mathrm{O}$ mole fraction & \\
\hline
\end{tabular}

$$
T\left({ }^{\circ} \mathrm{K}\right)=\left(\left(\frac{(A+X)^{2}(B+0.75 X)^{1.5} \pi^{0.5}}{(C-X)^{2}\left(1 / 3 f_{i\left(\mathrm{H}_{2} \mathrm{~S}\right)}-0.5 X\right)(D+0.25)^{0.5}}+420.49\right) / 0.6021\right)+273
$$


Table 4. Calculated parameters for case study.

\begin{tabular}{ccccc}
\hline $\mathrm{i}$ & $\mathrm{A}_{\mathrm{i}}$ & $\mathrm{B}_{\mathrm{i}}$ & $\mathrm{C}_{\mathrm{i}}$ & $\mathrm{D}_{\mathrm{i}}$ \\
\hline- & 560.6297 & -6.5079 & 589.4866 & 3748.3 \\
0 & $2.0757 \times 10^{8}$ & $4.3965 \times 10^{4}$ & - & - \\
4 & $-1.1318 \times 10^{5}$ & -68.2566 & 0.0115 & $-2.3178 \times 10^{-7}$ \\
5 & 12.6875 & 0.014 & $3.7 \times 10^{-6}$ & $3.875 \times 10^{-10}$ \\
\hline
\end{tabular}

nace model on design, overall sulfur recovery and emissions, this modified Claus plant was simulated using SULSIM $^{\circledR}$.

SULSIM $^{\circledR}$ is program for Sulfur Plant Simulation and represents simulation package for SRU and TGTU design. This software has widely accepted thermodynamic data and propriety thermodynamic properties for all of the gas components and sulfur species found in sulfur recovery processes. Figure 2 shows the flow diagram of the simulated Claus unit of Shahid Hasheminejad Gas Refinery.

\section{Results and Discussion}

As described previously, we implemented real data from gas refinery in the model. In this section to verify the model, we compare the output result from reaction furnace, model values and simulation results. Table 5 listed three set of results.

It is obvious that furnace temperature obtained using model $(1098 \mathrm{~K})$ is lower than actual temperature of reaction furnace $(1113 \mathrm{~K})$, as the $15^{\circ} \mathrm{C}$ temperature difference is negligible and it results into $1.35 \%$ error. Simulated results shows that predicted temperature using SULSIM $^{\circledR}$ software is $1121 \mathrm{~K}$ and higher than Claus furnace temperature. Error occurred using software is lower $(0.72 \%)$. In this case simulation is more reliable. Additionally, sulfur conversion obtained from model results $(56.635 \%)$ is in good agreement with conversion of sulfur in Claus plant (54\%) in gas refinery. On the other hand, results from simulation indicate that sulfur conversion is $60.28 \%$. According to the fact that obtained conversions from model are attained in lower temperature in comparing with the plant temperature while sulfur product is higher, we can conclude that model is more efficient in sulfur conversion. It is obvious that presented model in these conditions, is effective even more than simulated process. As it is presented in the Table 5, in the furnace effluent there is sulfur vapor. It's due to the high temperature in the furnace; this high temperature converts sulfur to $S_{2}$ vapor. According to Table 5, inlet air ratio to acid gas feed in Claus plant is 0.86 and in our model this ratio is 0.83 . As we used this obtained ratio in our simulation, simulation and modeling resulted in the same ratio. Therefore modeling and simulation errors are low and about 3.5\%. Since sulfur production is high in comparing with actual plant; air consumption is low, $\mathrm{CO}_{2}$ concentration difference is about 0.05 (mole \%), it means error is $0.34 \%$; we can conclude that in all cases, simulated and modeling are more efficient.

Predicted $\mathrm{N}_{2}$ concentration using equilibrium model is 36.067 (mole \%) whereas $\mathrm{N}_{2}$ content in the plant outlet gas stream is 39 (mole \%). Since In empirical equations of model, it is assumed air consumption is low, results are logic and difference between real state and model results is acceptable. Since air consumption is low, its acid gas capacity is more than actual plant and can predict better results. Simulation has the same manner in the prediction of $\mathrm{N}_{2}$ concentration. $\mathrm{H}_{2} \mathrm{O}$ concentration in the outlet stream from model is less than plant outlet water content. The model performance was not good in water case and error value is about $7.8 \%$. While $\mathrm{H}_{2} \mathrm{O}$ content in simulation is closer to the actual data and lower error has occurred. Simulation performance is better in this case.

$\mathrm{O}_{2}$ component in Claus plant damages the equipments (catalyst exchanger) and must be minimized, in Claus plants $\mathrm{O}_{2}$ content is zero. Predicted concentration is

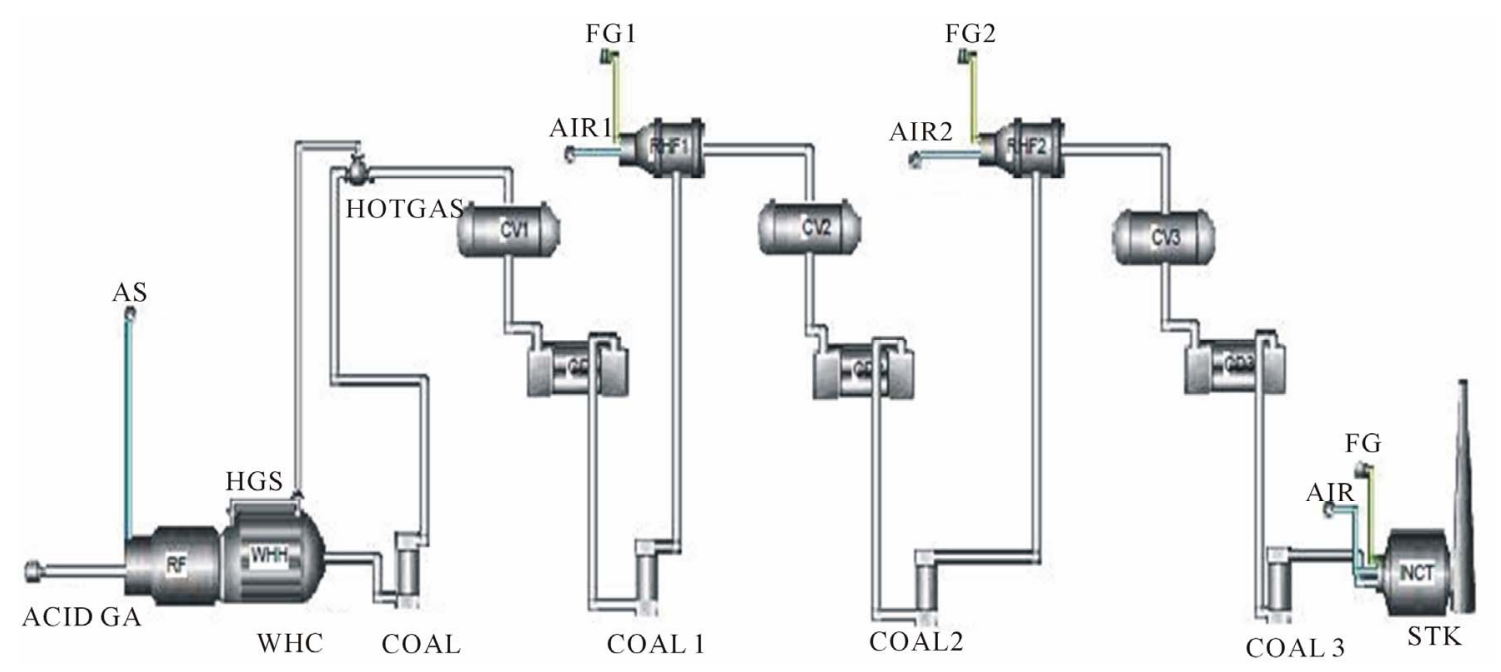

Figure 2. SULSIM ${ }^{\circledR}$ simulation used for gas for Khangiran gas refinery (S.G.P.C). 
Table 5. Comparison of plant value and results from model and simulation for S.G. P.C.

\begin{tabular}{|c|c|c|c|}
\hline $\begin{array}{l}\text { Condition of } \\
\text { Outlet Stream }\end{array}$ & $\begin{array}{l}\text { Actual values } \\
\text { for outlet } \\
\text { concentration } \\
\text { from W.H.B in } \\
\text { Claus unit }\end{array}$ & $\begin{array}{c}\text { Predicted } \\
\text { Values using } \\
\text { Model }\end{array}$ & $\begin{array}{c}\text { Predicted } \\
\text { Values using } \\
\text { SULSIM }^{\circledR} \\
\text { simulation }\end{array}$ \\
\hline $\mathrm{T}$ (furnace temp) & $1113 \mathrm{~K}\left(840^{\circ} \mathrm{C}\right)$ & $1098 \mathrm{~K}\left(825^{\circ} \mathrm{C}\right)$ & $1121 \mathrm{~K}\left(848^{\circ} \mathrm{C}\right)$ \\
\hline $\mathrm{F}_{\text {out }}(\mathrm{kgmole} / \mathrm{hr})$ & 4789.7 & 4879.593 & 4882.196 \\
\hline $\mathrm{X}_{\mathrm{CH}_{4}}(\mathrm{~mole} \%)$ & 0 & 0 & 0 \\
\hline $\mathrm{X}_{\mathrm{CO}_{2}}($ mole $\%)$ & 31 & $31.105 \%$ & $30.698 \%$ \\
\hline $\mathrm{X}_{\mathrm{H}_{2} \mathrm{~S}}(\mathrm{~mole} \%)$ & $4.9 \%$ & $5.051 \%$ & $4.952 \%$ \\
\hline $\mathrm{X}_{\mathrm{H}_{2} \mathrm{O}} \quad(\mathrm{mole} \%)$ & $20.1 \%$ & $18.519 \%$ & $19.214 \%$ \\
\hline $\mathrm{X}_{\mathrm{O}_{2}}(\operatorname{mole} \%)$ & $0 \%$ & $0.014 \%$ & 0 \\
\hline $\mathrm{X}_{\mathrm{N}_{2}} \quad(\operatorname{mole} \%)$ & $39 \%$ & $36.067 \%$ & $36.076 \%$ \\
\hline $\mathrm{X}_{\mathrm{SO}_{2}} \quad(\mathrm{~mole} \%)$ & $2.8 \%$ & $2.643 \%$ & $2.301 \%$ \\
\hline $\mathrm{X}_{\mathrm{S}_{2}} \quad(\mathrm{~mole} \%)$ & $1 \%$ & $5.139 \%$ & $5.516 \%$ \\
\hline $\mathrm{X}_{\mathrm{CO}}(\mathrm{mole} \%)$ & $0.2 \%$ & $0.325 \%$ & $0.737 \%$ \\
\hline $\mathrm{X}_{\mathrm{COS}, \mathrm{CS}_{2}} \quad(\operatorname{mole} \%)$ & $0.9 \%$ & $0.102 \%$ & $0.081 \%$ \\
\hline $\mathrm{X}_{\mathrm{H}_{2}}(\mathrm{~mole} \%)$ & $0.1 \%$ & $1.035 \%$ & $0.425 \%$ \\
\hline Ratio (air/feed) & 0.86 & 0.83 & 0.83 \\
\hline Sulfur conversion & $54 \%$ & $55.635 \%$ & $60.28 \%$ \\
\hline
\end{tabular}

$0.014 \%$ and error value is acceptable. The model predicted $\mathrm{CH}_{4}$ concentration would drop to zero in the outlet of furnace. Checking the actual outlet concentration it is obvious that there is no methane in outlet stream, therefore no error has occurred in predicting of methane concentration. Table 5 represents actual data for the concentration of $\mathrm{CS}_{2}$ and $\mathrm{COS}$ are greater than equilibrium model, data obtained from simulation. As you know, production of $\mathrm{CS}_{2}$ and COS in the Claus furnace reduces the efficiency of total plant and it is better to decrease these components. Therefore simulation and model outputs are more effective. According to Sames (1990), COS forms in WHB exchanger, therefore difference between predicted concentration and plant data verifies the formation reaction of COS [14]. This take place in W.H.B as following equation:

$$
\mathrm{CO}+1 / 2 \mathrm{~S}_{2} \rightarrow \mathrm{COS}
$$

Predicted $\mathrm{S}_{2}$ content in both methods is greater than plant data. There is a big difference between real and predicted values for $\mathrm{S}_{2}$; it is due to the formation of liquid sulfur in WHB. According to Table 5 and comparison between results and plant data, and also neglecting the error in $\mathrm{CO}$ and $\mathrm{H}_{2}$ predicted concentrations, average error is about $3.5 \%$ and $5.36 \%$ for model and SULSIM $^{\circledR}$ simulation; also AAD (Average Absolute Deviation) in comparing actual data with modeling and simulation results are $2.07 \%$ and $4.92 \%$, respectively. We can conclude that our model is more efficient and applicable for other Claus plants with different inlet composition.

\section{1. $\mathrm{H}_{2} \mathrm{~S}$ Concentration Effects}

Figure 3 shows reaction furnace predicted temperature vs. inlet $\mathrm{H}_{2} \mathrm{~S}$ content using model and simulation. Both simulation and model have similar trend. According to the figure, model predicts that $1 \%$ increase in $\mathrm{H}_{2} \mathrm{~S}$ content will result into $7.5^{\circ} \mathrm{C}$ increase in furnace temperature. In order to combust hydrocarbons and aromatics, furnace temperature must be $1050^{\circ} \mathrm{C}$. According to the model, if inlet gas stream contains more than $26 \% \mathrm{H}_{2} \mathrm{~S}$ in current plant, temperature would increase to higher than $1050^{\circ} \mathrm{C}$ $(1323 \mathrm{~K})$. Figures 4(a) and (b) illustrate the predictions of model and simulation for $\mathrm{H}_{2} \mathrm{~S}$ and sulfur conversion in furnace vs. increase in $\mathrm{H}_{2} \mathrm{~S}$ content in feed. As model predicts, for one percent of the mole fraction of $\mathrm{H}_{2} \mathrm{~S}$ in feed stream, sulfur conversion increases by $0.54 \%$ in reaction furnace and $\mathrm{S}_{2}$ mole fraction in outlet gas stream increases $0.12 \%$. Simulation has similar manner in this case. Obtained results both are matched. It should be noted that sulfur conversion in Figure 4(b) shows model and simulation have similar trend. Therefore there is a negligible difference between the model and simulation prediction in $18 \% \mathrm{H}_{2} \mathrm{~S}$ in Figure 4(a). It is due to errors occurred in the simulation.

Figure 5 shows the effect of $\mathrm{H}_{2} \mathrm{~S}$ concentration in feed stream on the effluent $\mathrm{H}_{2} \mathrm{~S}$ content. As $\mathrm{H}_{2} \mathrm{~S}$ content increase in the feed, model predicts a trend for $\mathrm{H}_{2} \mathrm{~S}$ content in outlet which decreases and then with a lower slope increases and finally decreases.

The results indicate that in lower concentrations, furnace temperature is low and increase in the $\mathrm{H}_{2} \mathrm{~S}$ (to $30 \%$ ) content would increase the slope of $\mathrm{H}_{2} \mathrm{~S}$ conversion line that results to decrease in $\mathrm{H}_{2} \mathrm{~S}$ content in the outlet stream of furnace.

In the higher concentrations, since furnace temperature is more than previous, $\mathrm{H}_{2} \mathrm{~S}$ cracking and conversion in Claus reaction increases and unconverted hydrogen sulfide

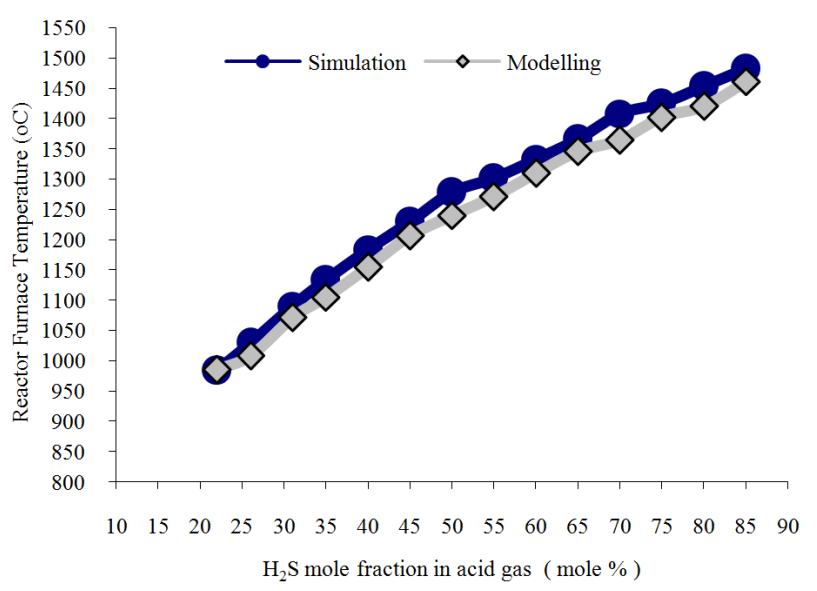

Figure 3. Simulation and model estimation for Modified Claus plant reaction furnace temperature vs. $\mathrm{H}_{2} \mathrm{~S}$ content. 


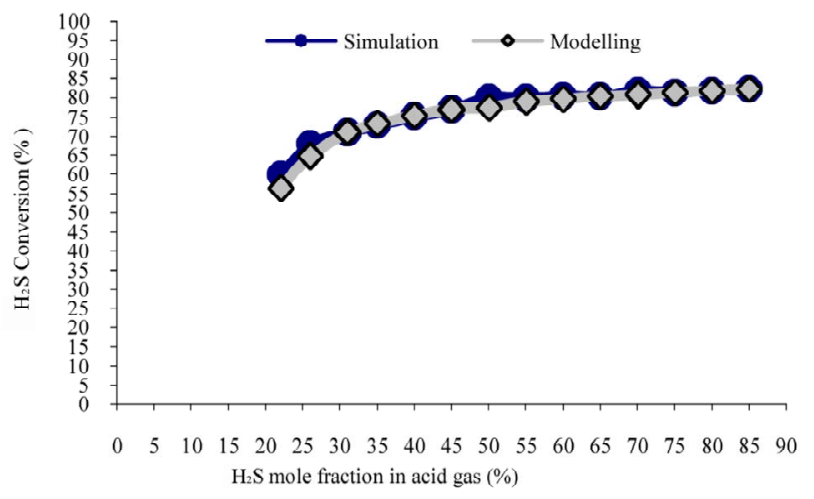

(a)

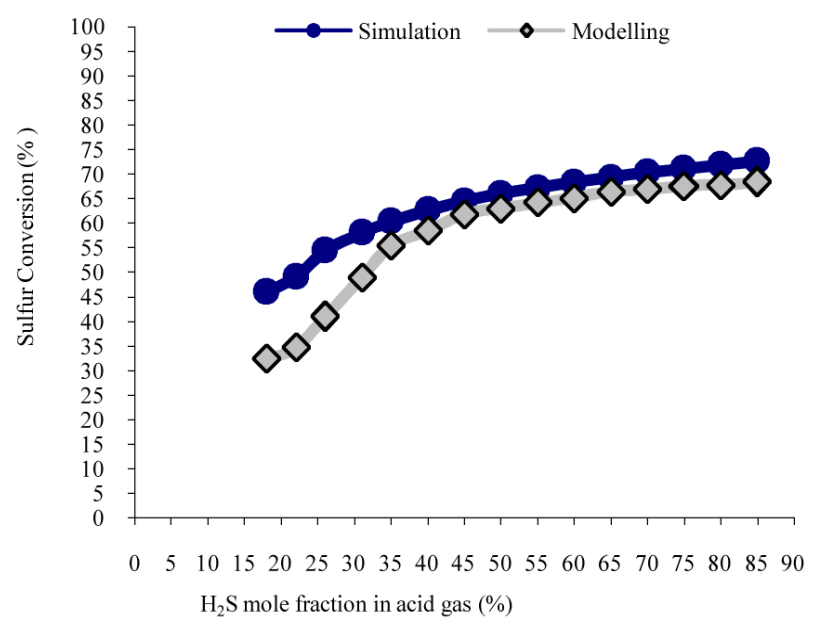

(b)

Figure 4. Comparison of predicted. (a) $\mathrm{H}_{2} \mathrm{~S}$ conversion; (b) sulfur conversion vs. $\mathrm{H}_{2} \mathrm{~S}$ mole fraction in feed stream.

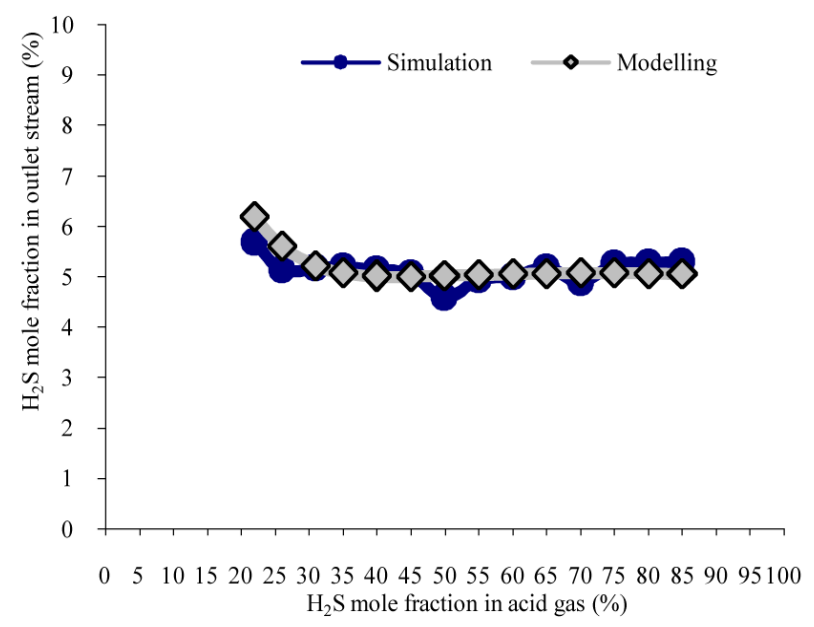

Figure 5. Estimation for $\mathrm{H}_{2} \mathrm{~S}$ content in outlet stream vs. $\mathrm{H}_{2} \mathrm{~S}$ mole fraction in feed stream.

in the outlet decreases. As can be seen in the figure, the reduction of $\mathrm{H}_{2} \mathrm{~S}$ in the effluent is agreement with increase in $\mathrm{H}_{2} \mathrm{~S}$ content in acid feed gas. For this case, model prediction is more reliable than simulation.

\subsection{Effect of Inlet Temperature}

In this section, temperature effects have been investigated. We can predict the effect of preheating on the furnace temperature and conversion in furnace. Figure 6(a) shows the variation of furnace temperature vs. inlet temperature of acid gas. According to the figure, furnace temperature increases $4.4^{\circ} \mathrm{C}$ by $10^{\circ} \mathrm{C}$ increase in inlet temperature. Therefore, if we can increase the design temperature $\left(52^{\circ} \mathrm{C}\right)$ to $252^{\circ} \mathrm{C}$, furnace reactions will take place in $914^{\circ} \mathrm{C}$.

Figure 6(b) shows the $\mathrm{H}_{2} \mathrm{~S}$ conversion by increase in the temperature. As can be seen from Figure 6, $\mathrm{H}_{2} \mathrm{~S}$

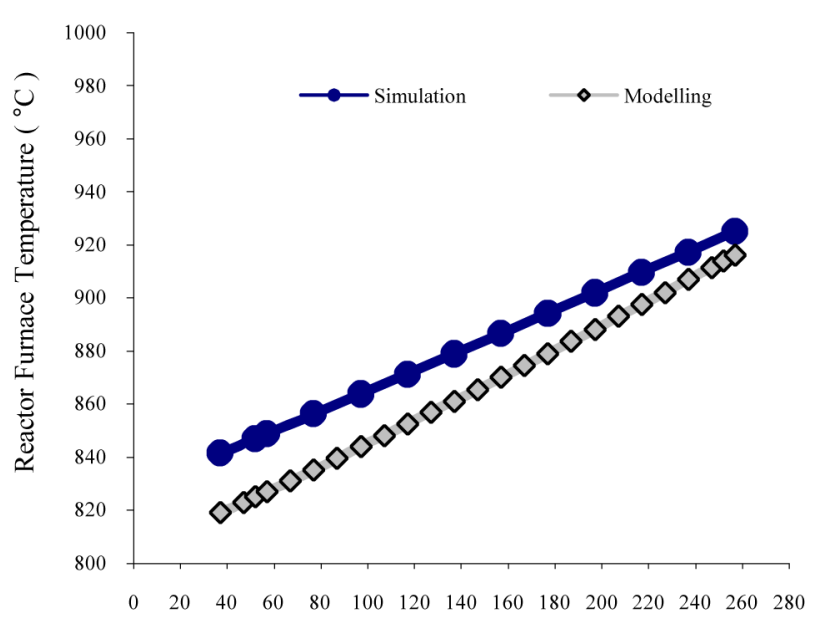

Acid gas temperature $\left({ }^{\circ} \mathrm{C}\right)$

(a)

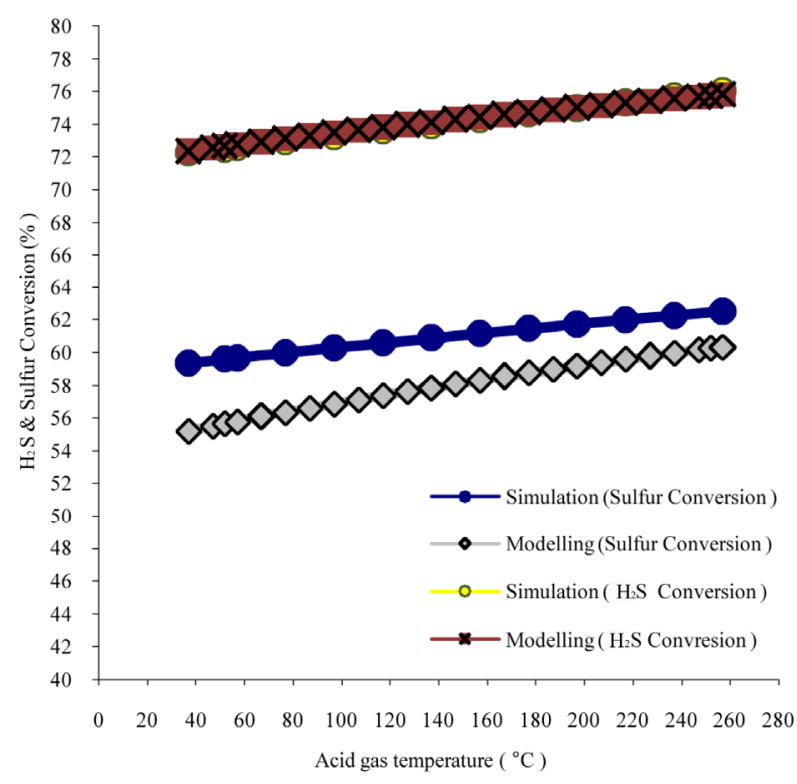

(b)

Figure 6. (a) Modified Claus furnace temperature prediction for Khangiran Gas refinery vs. inlet acid gas temperature; (b) $\mathrm{H}_{2} \mathrm{~S}$ and sulfur conversion vs. inlet acid gas temperature. 
conversion increases by $0.156 \%$ when inlet temperature increases $10^{\circ} \mathrm{C}$. Also this figure demonstrates that $\mathrm{H}_{2} \mathrm{~S}$ conversion in furnace would increases from $72.66 \%$ to $75.74 \%$ in preheated feed $\left(252^{\circ} \mathrm{C}\right)$.

Also $10^{\circ} \mathrm{C}$ increase in temperature of inlet air results into $2.52^{\circ} \mathrm{C}$ increases in furnace temperature, $0.103 \%$ increase in $\mathrm{H}_{2} \mathrm{~S}$ conversion and $0.153 \%$ increase in sulfur conversion. If both acid gas feed and inlet air preheated separately and equally $10^{\circ} \mathrm{C}$, reaction furnace temperature increases $7.1^{\circ} \mathrm{C}, \mathrm{H}_{2} \mathrm{~S}$ conversion $0.21 \%$ and sulfur conversion $0.31 \%$.

From a theoretical point of view, there is an optimal temperature in the furnace reactor to get the more efficient performance, maximizes sulfur production and $\mathrm{H}_{2} \mathrm{~S}$ conversion as reported in the previous sections for Claus process. A solution for this problem is fuel gas injection to the furnace in order to increase the temperature. By one percent increase fuel content in the inlet gas, furnace temperature would increase $30^{\circ} \mathrm{C}-50^{\circ} \mathrm{C}$. Calculation showed that $2000 \mathrm{Sm}^{3} / \mathrm{hr}$ fuel injections in acid gas feed $\left(50000 \mathrm{Sm}^{3} / \mathrm{hr}\right)$ for Shahid Hasheminejad Refinery, furnace temperature would increase $130^{\circ} \mathrm{C}$. More hydrocarbon content in the feed will produces more $\mathrm{CS}_{2}$ and $\mathrm{COS}$ in the furnace. Increasing flow rate causes decrease in furnace capacity. It was observed the positive effect of fuel injection by increasing the temperature, led to reduction in plant capacity.

\section{Conclusion}

The reactor furnace for an industrial three-stage straightthrough sulfur plant with identical feed gas composition and operating conditions was molded and compared. The results of the modeling and steady state simulation have been presented in Table 5. The results showed that $\mathrm{H}_{2} \mathrm{~S}$ conversion could be promoted by an increase in hydrogen sulfide content in the feed gas. Therefore if we could enhance the $\mathrm{H}_{2} \mathrm{~S}$ concentration, sulfur conversion and overall efficiency of the furnace would improve. This also could lead to decomposition of aromatic compounds such as BTEX, additionally furnace temperature would increase. In order to increase furnace temperature, fuel injection is possible but, it must be optimized to prevent plant capacity reduction. On the other hand, reduction in $\mathrm{CO}_{2}$ and $\mathrm{N}_{2}$ inlet flow helps to reduce the volume of effluent and increases the furnace capacity in the Claus plant. Also results demonstrated that by utilization of heat input (preheated feed and air) in a furnace of a plant, the performance of the reactor would improve.

\section{REFERENCES}

[1] M. Sassi and A. K. Gupta, "Sulfur Recovery from Acid Gas Using the Claus Process and High Temperature Air Combustion (HiTAC) Technology," American Journal of
Environmental Sciences, Vol. 4, No. 5, 2008, pp. 502-511. doi:10.3844/ajessp.2008.502.511

[2] K. Karan, "An Experimental and Modeling Study of Homogeneous Gas Phase Reactions Occurring in the Modified Claus Process," Ph.D. Thesis, University of Calgary, Calgary, 1998.

[3] W. D. Monnery, et al., "Modeling the Modified Claus Process Reaction Furnace and the Implications on Plant Design and Recovery," The Canadian Journal of Chemical Engineering, Vol. 71, No. 5, 1993, pp. 711-724. doi:10.1002/cjce.5450710509

[4] K. A. Hawboldt, "Kinetic Modeling of Key Reaction in the Modified Claus Plant Front End Furnace," Thesis, University of Calgary, Calgary, 1998.

[5] S. Asadi, et al., "Effect of $\mathrm{H}_{2} \mathrm{~S}$ Concentration on the Reaction Furnace Temperature and Sulphur Recovery," International Journal of Applied Engineering Research, Vol. 1, No. 4, 2011, p. 961.

[6] H. G. Paskall, "Capability of the Modified-Claus Process: A Final Report to the Department of Energy and Natural Resources of the Province of Alberta," Western Research \& Development, Cheyenne, 1979.

[7] H. G. Paskall, "Reaction Furnace Chemistry and Operational Models," Sulphur Recovery, Western Research, Calgary, 1981.

[8] P. D. Clark, et al., "Mechanism of $\mathrm{CS}_{2}$ Formation in the Claus Front-End Reaction Furnace," Proceedings of the 47th Annual Laurance Reid Gas Conditioning Conference, Norman, 2-5 March 1997, pp. 321-337.

[9] P. D. Clark, et al., "Mechanisms of CO and COS Formation in the Claus Furnace," Industrial Engineering and Chemistry Research, Vol. 40, No. 2, 2001, pp. 497-508. doi:10.1021/ie9908711

[10] P. A. Tesner, M. N. Nemirovskii and D. N. Motyl, "Kinetics of the Thermal Decomposition of Hydrogen Sulphide at $600-1200^{\circ} \mathrm{C}$," Kinetics and Catalysis, Vol. 31, 1990, p. 1232.

[11] B. Goar, et al. "Sulfur Recovery Technology," Energy Progress, Vol. 6, No. 2, 1986, pp. 71-75.

[12] J. A. Sames and H. G. Paskall, "Simulation of Reaction Furnace Kinetics for Split-Flow Sulphur Plants," Sulphur Recovery, Western Research, Calgary, 1990.

[13] E. A. Luinstra and P. E. Haene, "Catalyst Added to Claus Furnace Reduces Sulfur Losses," Hydrocarbon Process, Vol. 68, No. 7, 1989, pp. 53-60.

[14] J. A. Sames, et al., "Evaluation of Reaction Furnace Variables in Modified Claus Plants," Sulphur Recovery, Western Research, Calgary, 1990. 


\section{Appendix}

The Western Research (Sames and Paskall) correlations are given below:

$\mathrm{R}(\mathrm{CO})=0.002 \mathrm{~A}^{0.0345} \exp (4.534 \mathrm{~A})$
$\mathrm{R}\left(\mathrm{H}_{2}\right)=$ fraction of furnace inlet $\mathrm{H}_{2} \mathrm{~S}$ that cracks to $\mathrm{H}_{2}$ and $\mathrm{S}$

$\mathrm{R}\left(\mathrm{H}_{2}\right)=0.056( \pm 0.024)$

$\mathrm{R}(\mathrm{COS})=$ fraction of furnace inlet carbon that forms $\operatorname{COS}$

$\mathrm{R}(\mathrm{COS})=0.01$ tangent $(100 \mathrm{~A})$ for $0 \leq \mathrm{A} \leq 0.86$

$\mathrm{R}(\mathrm{COS})=0.143$ for $\mathrm{A}>0.86$

$\mathrm{R}\left(\mathrm{CS}_{2}\right)=$ fraction of furnace inlet hydrocarbon that forms $\mathrm{CS}_{2}$

$\mathrm{R}\left(\mathrm{CS}_{2}\right)=2.6 \mathrm{~A}^{0.971} \exp (-0.965 \mathrm{~A})$

$R(S)=$ fraction of furnace inlet $\mathrm{H}_{2} \mathrm{~S}$ that forms elemental S

$\mathrm{R}(\mathrm{S})=1.58 \mathrm{~A}^{1.099} \exp (-0.73 \mathrm{~A})$ where $\mathrm{A}=$ mole fraction of $\mathrm{H}_{2} \mathrm{~S}$ in the acid gas feed on a dry basis.

\section{Nomenclature}

$f_{i}$ : Molar flow rate of $i^{\text {th }}$ compound

$X$ : Mole fraction of compound

$R(i)$ : fraction of furnace inlet of $i^{\text {th }}$ compound

$K_{p}$ : Equilibrium constant

$T$ : temperature

$\pi$ : furnace total pressure

$C_{p, i}$ : Heap capacity of $i^{\text {th }}$ compound

$\Delta H_{r x x}$ : Reaction enthalpy

$H_{i, 298}{ }^{\circ}$ : Standard enthalpy of $i^{\text {th }}$ compound formation

W.H.B: Waste Heat Boiler 